\title{
Physical Characteristics, Shade Distribution, and Tall Fescue Effects on Cow Temporal/ Spatial Distribution in Midwestern Pastures
}

\author{
Douglas A. Bear, ${ }^{1}$ James R. Russell, ${ }^{2}$ and Daniel G. Morrical ${ }^{2}$ \\ Authors are ${ }^{1}$ Research Assistant and ${ }^{2}$ Professor, Department of Animal Science, Iowa State University, Ames, IA 50011, USA.
}

\begin{abstract}
Nonpoint source (NPS) pollution of water resources may occur from congregation of cattle near streams or ponds. Therefore, relationships of physical characteristics, shade distribution, and tall fescue (Festuca arundinacea Schreb.) prevalence in coolseason grass pastures to the temporal/spatial distribution of grazing cattle were evaluated in two studies on beef cow/calf farms. Global positioning system (GPS) collars recorded the location of 2-3 cows per pasture at 10-min intervals for 5-14 $\mathrm{d}$ in the spring, summer, and fall annually. Pasture botanical composition was visually assessed annually. In Study 1, cow location was recorded on five pastures ranging in size from 13 ha to 125 ha with $1.9-3.8 \%$ of the pasture area in a stream or pond (water source) and $2-30 \%$ of the pasture area within $30.5 \mathrm{~m}$ of the water source (waterside zone) for $3 \mathrm{yr}$. Shade covered $27-73 \%$ of the pasture area with 3-64\% of shade located within waterside zone. In Study 2, cow location was recorded in three pastures with areas of 8 ha, 10 ha, and 15 ha with $17.8 \%, 43.4 \%$, and $14.7 \%$ of the total area and $28 \%, 73 \%$, and $68 \%$ of the total shade in the waterside zone for $1 \mathrm{yr}$. In Study 1, proportions of cow observations within the waterside zone increased with decreasing pasture area $\left(r^{2}=0.61\right)$ and increasing proportions of the total pasture area $\left(r^{2}=0.37\right)$ and shade $\left(r^{2}=0.29\right)$ within the waterside zone. In Study 2, proportion of cow observations in the waterside zone increased as the proportion of total area $\left(r^{2}=0.62\right)$ and shade $\left(r^{2}=0.42\right)$ in the waterside zone increased. Results imply more restrictive measures to minimize the risks of NPS pollution of water resources may be most effective in smaller and narrow pastures.
\end{abstract}

\section{Resumen}

La contaminación de origen no identificado (NPS) de los recursos hídricos, puede ocurrir debido a la congregación del ganado cerca de los arroyos o estanques. Por lo tanto, las relaciones de las características físicas, distribución de la sombra y la incidencia de Festuca alta (Festuca arundinacea Schreb.) en potreros con gramíneas de crecimiento invernal en la distribución temporal/espacial del pastoreo del ganado se evaluaron en dos estudios en una granja de vaca-becerro. Collares de sistema de posicionamiento global (GPS) registraron la ubicación de 2 a 3 vacas por potrero a intervalos de 10 minutos de 5 a 14 en la primavera, verano y otoño anualmente. La composición botánica de los potreros se evaluó visualmente cada año. En el estudio 1, conducido durante tres años, la ubicación de las vacas se registró en cinco potreros con un rango de 13 a 125 hectáreas de extensión, con 1.9 a $3.8 \%$ de la superficie del potrero en arroyos o estanques (fuente de agua) y 2 a $30 \%$ de la superficie del potrero dentro de $30.5 \mathrm{~m}$ de distancia de la fuente de agua (zona de agua) para 3 años. Los sombreaderos cubrieron de 27 a $37 \%$ del área del potrero con 3 a $64 \%$ de la sombra ubicada dentro de la zona del agua. En el estudio 2, la ubicación de las vacas se registró en tres potreros con áreas de 8, 10, y 15 hectáreas con 17.8, 43.4 y $14.7 \%$ de la superficie total y 28,73 y $68 \%$ de la sombra total en la zona del agua y se evaluó durante un año. En el estudio 1, las proporciones de las observaciones de las vacas dentro de la zona del agua aumentaron con la disminución de la superficie del potrero $\left(\mathrm{r}^{2}=0.61\right)$ y aumentaron las proporciones de la superficie total del potrero $\left(\mathrm{r}^{2}=0.37\right)$ y con la sombra $\left(\mathrm{r}^{2}=0.29\right)$ dentro de la zona del agua. En el estudio 2, aumento la proporción de observaciones de vaca en la zona del agua conforme la proporción de la superficie total $\left(\mathrm{r}^{2}=0.62\right)$ y sombra $\left(\mathrm{r}^{2}=\right.$ 0.42) en la zona del agua aumentó. Estos resultados sugieren medidas más preventivas para minimizar los riesgos de contaminación de NPS en los recursos hídricos y puede ser más eficaz en potreros más estrechos y pequeños.

Key Words: beef cows, GPS pasture size, grazing, shade, water quality

\section{INTRODUCTION}

Research was funded by the Cooperative State Research, Education, and Extension Service, USDA under Award 2006-51130-03700. Any opinions, findings, conclusions, or recommendations expressed in this publication are those of the authors and do not necessarily reflect the views of the US Department of Agriculture. This material is also supported, in part, by the lowa State University Leopold Center for Sustainable Agriculture.

Mention of a proprietary product does not constitute a guarantee or warranty of the product by lowa State University or the authors and does not imply its approval to the exclusion of other products that also may be suitable.

Correspondence: J. R. Russell, Dept of Animal Science, 313 Kildee Hall, Ames, IA 50011, USA. Email: jrussel|@iastate.edu

Manuscript received 26 April 2011; manuscript accepted 31 March 2012.
Much of the heat gained by cattle from the environment during daylight hours occurs by solar radiation (Fuquay 1981). Therefore, providing shade for cattle reduces the deleterious effects of heat stress (Tucker et al. 2008). Because both shade and water are present in pasture riparian areas, grazing cattle congregate near pasture streams to maintain thermoregulation (Kauffman and Krueger 1984; Bailey 2005; Franklin et al. 2009). Because distribution of cattle and nutrient excretions are related (Tate et al. 2003), congregation of cattle will increase concentrations of fecal nutrients and pathogens near shade and water resources (White et al. 2001; Ballard and Krueger 2005). 
Research on western rangelands implies that overutilization of pasture riparian areas by livestock negatively impacts riparian ecosystems (Kauffman and Krueger 1984; DelCurto et al. 2005; Ganskopp and Bohnert 2009) and surface water quality (Belsky et al. 1999). Because the impairment of thermoregulation in grazing cattle is exacerbated by increased environmental temperatures (Zuo and Miller-Goodman 2004) and endophyte-infected tall fescue (Festuca arundinacea Schreb.; Al-Haidary et al. 2001) common to the humid eastern United States, risks of sediment, nutrient, and pathogen loading of water resources may be elevated in this region.

Relationships have been established between distribution of grazing livestock and pasture characteristics such as size and shape (Bryant 1982; Hart et al. 1993; Sevi et al. 2001), shade distribution (McIlvin and Shoop 1971; Blackshaw and Blackshaw 1994), and botanical composition (Bailey et al. 1996; Ganskopp and Bohnert 2009) on western rangelands. But because rangeland pastures tend to be large and more heterogeneous in botanical composition and terrain (Bailey 2005; Bailey et al. 2008; Ganskopp and Bohnert 2009), and to contain less tall fescue than midwestern pastures (DelCurto et al. 1999; McInnis and McIver 2001), it is unclear whether these relationships apply to midwestern pastures.

Therefore, objectives of this project were to evaluate the effects of pasture physical characteristics, shade distribution, and tall fescue prevalence in relation to climatic factors on the temporal/spatial distribution of grazing cattle in midwestern pastures. These objectives were addressed through two studies to provide site-specific information in midwestern pastures to assist producers with management decisions to further minimize grazing cattle's impact on water quality.

\section{MATERIALS AND METHODS}

\section{Site Description}

Study 1. Five pastures in the Rathbun Lake watershed in southern Iowa on cooperating beef cow/calf operations were identified as appropriate for the project in the fall of 2006. Sites selected for the project were based on the producer's willingness and ability to handle cattle for attaching and detaching GPS collars two times during the spring, summer, and fall grazing seasons over a 3-yr period (2007-2009) and if the pasture contained a perennial flowing stream or pond in which cattle had uncontrolled access. However, only four of original five pastures were used during the 2009 grazing season, as Farm A was subdivided and used as described in Study 2. Pastures ranged in size from 13.5 ha to 125.2 ha (Table 1). The landscape within the Rathbun Lake watershed is characterized by rolling uplands, integrated drainage, and some occasional broad alluvial plains, which limits use, as soils are moderately and highly erosive, root-restricted, excessively wet, and low in fertility (Rathbun Land and Water Alliance [RLWA], 2001). Major soil types within the pastures of the study included Adair, Caleb, Clarinda, Colo, Gara, Kniffin, Lawson-Nodaway, Olmitz-Vesseler-Colo, and Seymour with slopes ranging from $0 \%$ to $30 \%$ (NRCS Web Soil Survey ${ }^{1}$ ). Water sources in these pastures included both streams and ponds on Farms $\mathrm{C}$ and $\mathrm{E}$, streams on Farms A and D, and ponds on Farm B. In analysis of aerial photos with a maximum resolution of $1 \mathrm{~m}$ with the use of ArcGIS 9.2 (ESRI, Redlands, CA), a 10-m buffer from the center of each stream or edge of each pond was designated as the area of the water source. Areas within $30.5 \mathrm{~m}$ and greater than $30.5 \mathrm{~m}$ from a water source were referred to as the waterside zone and upland zone, respectively. Total pasture shade area and the proportion of total shade in the waterside zone were determined from aerial photos with the use of ArcGIS 9.2 (ESRI) software. The percentage of shade in the total pasture or waterside zone was determined by dividing the shaded area by the area in the total pasture or waterside zone, respectively. Waterside shade, as a percentage of the total pasture shade, was determined by dividing the area of waterside shade by the area of shade in the total pasture. Waterside zone comprised $2-30 \%$ of the total pasture area and contained $3-64 \%$ of the pasture shade.

Because of the limited number of producers willing to handle their cattle as frequently as required, there was considerable variability in cattle and pasture management. Cattle on Farm A

${ }^{1}$ http://websoilsurvey.nrcs.usda.gov/app/HomePage.htm

Table 1. Physical characteristics of pastures in Studies 1 and 2.

\begin{tabular}{|c|c|c|c|c|c|c|c|c|}
\hline \multirow[b]{2}{*}{ Farm/pasture } & \multirow[b]{2}{*}{ Year } & \multirow[b]{2}{*}{ Pasture size (ha) } & \multirow[b]{2}{*}{ Cattle breeds } & \multirow[b]{2}{*}{ Water source } & \multirow[b]{2}{*}{$\begin{array}{l}\text { Pasture shade } \\
\text { (\% of pasture area) }\end{array}$} & \multirow[b]{2}{*}{$\begin{array}{c}\text { Waterside zone } \\
\text { (\% of pasture area) }\end{array}$} & \multicolumn{2}{|c|}{ Waterside zone shade } \\
\hline & & & & & & & $\begin{array}{c}\text { (\% of } \\
\text { waterside zone) }\end{array}$ & $\begin{array}{c}\text { (\% of total } \\
\text { pasture shade) }\end{array}$ \\
\hline \multicolumn{9}{|l|}{ Study 1} \\
\hline A & 2007-2008 & 125.2 & Angus & Stream & 57.8 & 24.3 & 79.1 & 33.3 \\
\hline B & 2007-2009 & 64.9 & Angus & Ponds & 59.6 & 2.5 & 67.2 & 2.8 \\
\hline \multirow[t]{2}{*}{ C } & 2007 & 92.2 & Angus Cross & Stream and ponds & 30.5 & 17.2 & 79.1 & 44.8 \\
\hline & 2008-2009 & 29.2 & Angus Cross & Stream and ponds & 39.9 & 30.0 & 84.8 & 63.8 \\
\hline $\mathrm{D}$ & $2007-2009$ & 21.3 & Angus & Stream & 72.8 & 22.4 & 68.0 & 20.9 \\
\hline$E$ & 2007-2009 & 13.5 & Mexican Corriente & Stream and ponds & 27.2 & 28.7 & 55.5 & 58.4 \\
\hline \multicolumn{9}{|l|}{ Study 2} \\
\hline $1 \mathrm{~N}$ & 2009 & 15.1 & Angus & Stream & 19.4 & 14.7 & 89.7 & 67.6 \\
\hline $2 \mathrm{NE}$ & 2009 & 8.0 & Angus & Stream & 41.6 & 17.8 & 66.4 & 28.4 \\
\hline $3 S$ & 2009 & 9.9 & Angus & Stream & 21.8 & 43.4 & 36.5 & 72.6 \\
\hline
\end{tabular}




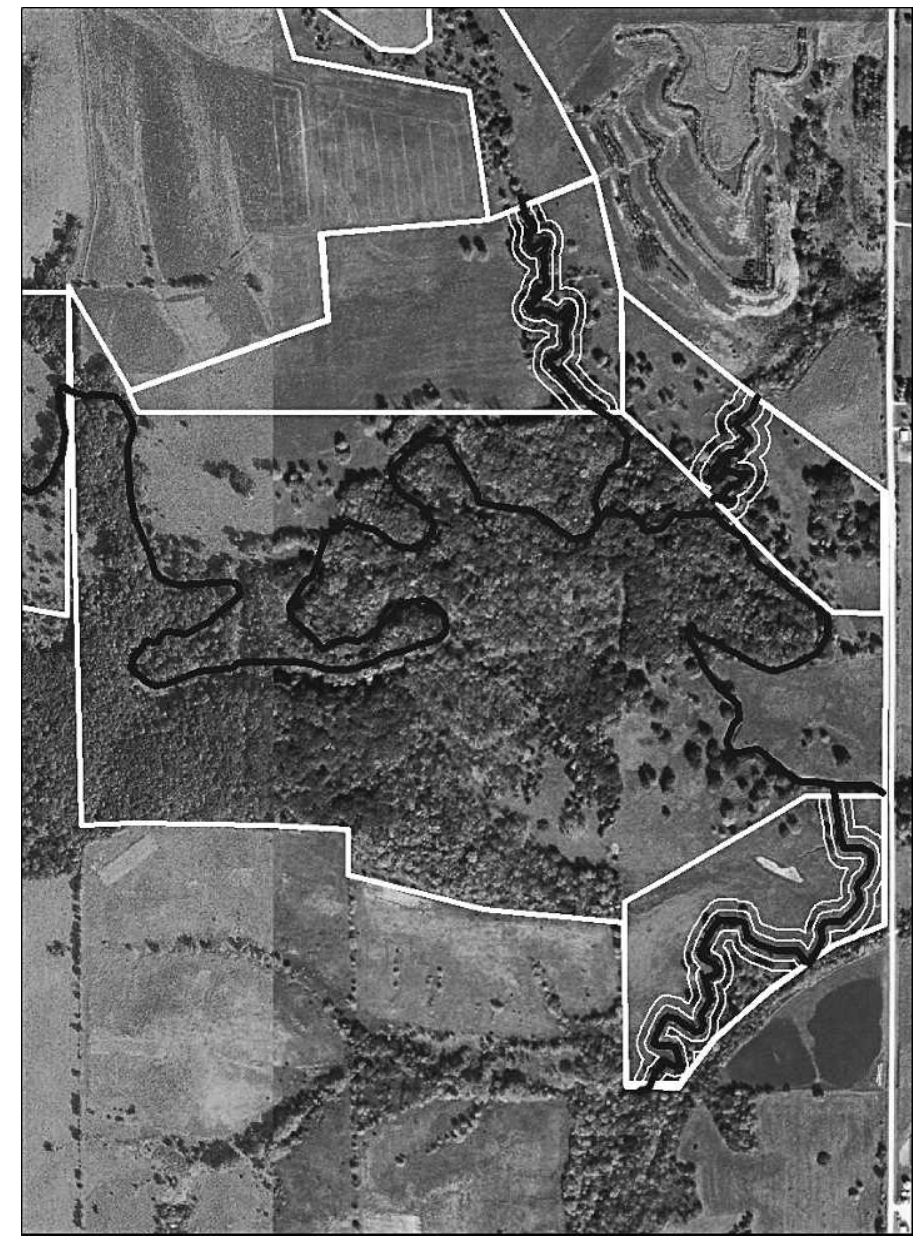

Figure 1. Aerial photo of pastures created on Farm A in 2009.

consisted of multiparous fall-calving Angus cows (Bos taurus L.) during the spring grazing seasons, and spring-calving cows during the summer and fall grazing seasons. Spring-calving heifers were used during the fall of 2007, because mature cows were unavailable. Farm D used multiparous fall-calving Angus cows during spring of 2007 and 2008 and multiparous springcalving cows during spring 2009. During summer of 2007 and 2009 and fall of 2007, 2008, and 2009, multiparous springcalving cows were used on Farm D. Cows used during the spring, summer, and fall grazing seasons of 2007-2009 were spring-calving, multiparous Angus, Angus-cross, and Mexican Corriente cows on Farms B, C, and E, respectively. Cows were rotationally stocked from March through November at 0.6 cows $\cdot \mathrm{ha}^{-1}, 0.7$ cows $\cdot \mathrm{ha}^{-1}$, and 1.5 cows $\cdot \mathrm{ha}^{-1}$ on Farms A, C, and $\mathrm{E}$, whereas cows were continuously stocked from March through November at 0.5 cows $\cdot \mathrm{ha}^{-1}$ and $1.9 \mathrm{cows} \cdot \mathrm{ha}^{-1}$ on Farms B and D, respectively, during the $3-y r$ grazing trial.

Study 2. In 2009, an additional study was conducted to evaluate the effects of shade distribution in pastures of more comparable sizes on cattle distribution. Part of the pasture on Farm A was divided into three pastures with sizes of 8.0 ha, 9.9 ha, and 15.1 ha (Table 1 and Fig. 1). The waterside zone comprised $17.8 \%, 43.4 \%$, and $14.7 \%$ of the total pasture area and contained $28.2 \%, 72.6 \%$, and $67.6 \%$ of the pasture shade, respectively. Mature fall-calving Angus cows were rotationally stocked during spring and summer and mature spring-calving cows were rotationally stocked during the fall with uncontrolled access to the streams at 1.0 cows $\cdot \mathrm{ha}^{-1}, 1.9$ cows $\cdot \mathrm{ha}^{-1}$, and 1.5 cows $\cdot \mathrm{ha}^{-1}$, respectively.

\section{Cattle Distribution}

Because of the need to synchronize the timing of attachment and detachment of the GPS collars with each cooperating producer's management schedule, GPS measurements were not conducted simultaneously on all farms. Instead, measurements among farms were grouped into the spring, summer, or fall seasons. Spring was defined as the vernal equinox to the summer solstice. Summer was defined as the summer solstice to the first day of the autumnal equinox. Fall was defined as the autumnal equinox to the winter solstice. In each season of both studies, two to three cows on each farm were randomly selected from the herd and fitted with custom prototype GPS collars (Engineering Services Group [ESG], Ames Laboratory, US Department of Energy, Ames, IA) with LEA-4S receivers (UBlox AG, Switzerland) that recorded cattle locations at 10-min intervals $24 \mathrm{~h} \cdot \mathrm{d}^{-1}$ for periods of 5-14 d. The GPS collars weighed approximately $1.65 \mathrm{~kg}$, less than $0.3 \%$ of a cow's body weight. Custom prototype collar accuracies have been previously reported by Schwarte et al. (2011). If collars stopped recording cattle locations before four complete days, the data set was not analyzed. Four days of data collection was an arbitrary number selected to allow adequate time for cattle to adjust to the collar and, if necessary, pasture. During the 3-yr study, technology failure of GPS collars occurred $10.9 \%$ of the time.

Collars were placed on two cows on Farm D during spring 2007, but both collars malfunctioned and did not collect data. During fall 2007, bred heifers were improperly fitted with collars on Farm A and two of the three collars were lost in the 125-ha pasture. During summer 2008, collars were not placed on cattle from Farm D, as flooding removed pasture fences. For determination of temporal/spatial distribution of the cattle, position coordinates of each GPS measurement were located on aerial maps with the use of ArcGIS 9.2 software (ESRI) and categorized as being located in the water source, waterside zone, or upland zone. The proportion of GPS observations within each zone was determined by the number of observations in each zone divided by the total number of GPS observations during the deployment of the collar. The proportion of observations in each zone was averaged from all collared cows in a pasture to determine the proportion of time in each zone in each season.

\section{Microclimatic Data}

A HOBO weather station (Onset Comp. Co., Bourne, MA), placed adjacent to the pastures on each of the five farms, recorded microclimate factors of ambient temperature (Temp), black globe temperature (BGTemp), dew point (DP), wind speed (WS) and direction, and relative humidity (RH) at 10min intervals during the grazing seasons. During summer 2008, three of the five weather stations were damaged by lightning and stopped recording data for approximately $4 \mathrm{wk}$. Therefore, the remaining two functioning weather stations in the closest proximity to the farms where cattle location was being 
determined at that time were used to replace missing data for the damaged weather stations. Microclimate factors were used to calculate effective temperature (ET; Yamamoto et al. 1994), temperature humidity indexes (THI; Buffington et al. 1981; Yousef 1985; Mader et al. 2006), and black globe temperature humidity indexes (BGTHI; Buffington et al. 1981; Meat and Livestock Australia 2002; Castañeda et al. 2003; Mader et al. 2006; Gaughan et al. 2008).

\section{Vegetative Composition and Cover}

In the spring of 2007, vegetative composition of each pasture in Study 1 was determined by dividing the three largest pastures (Farms A, B, C) into $100 \times 100 \mathrm{~m}$ grids and the two smaller pastures (Farms D and E) into $50 \times 50 \mathrm{~m}$ grids on aerial photos with the use of ArcGIS 9.2 software (ESRI). The pastures in Study 2 were evaluated with the use of the same $100 \times 100 \mathrm{~m}$ grid of the pasture on Farm A to maintain consistent evaluation of botanical composition from the two previous years. In late spring of each year, vegetative species of individual plants or bare ground at the center and at four equidistant locations from the center of each square of the grid in each pasture, as located by a handheld GPS receiver (Garmin 72, Overland Park, KS) were visually identified. Observations of individual forage species were divided by the number of herbaceous species within each grid and proportions of each herbaceous species from all surveyed grids were summed and divided by the total number of vegetated sites to determine the total percentage of herbaceous species within each pasture. The proportion of sites with shrubs or bare ground was calculated as a proportion of sites with these characteristics and divided by the total number of sites surveyed over the entire pasture. Because the majority of cool-season grasses were identified as tall fescue and reed canarygrass (Phalaris arundinacea L.) within the pastures, the remaining minimal proportions of cool-season grasses were combined and labeled as other cool-season grasses.

As vegetative composition was being determined in 2009, vegetative tillers of each tall fescue plant were hand plucked when identified in a grid within each pasture, placed in bags, and stored on ice for transport to the laboratory. One hundred fresh tall fescue tillers from each farm were randomly selected and evaluated for the presence of the ergot alkaloid-producing endophyte fungus (Neotyphodium coenophialum) by the procedure of Franklin et al. (2009). Samples testing positive for the endophyte were divided by total samples tested to determine the percentage of infected samples within each pasture.

\section{Statistical Analysis}

Effects of farm and season on the proportion of GPS observations within the water source or waterside zone of pastures in Study 1 were analyzed with the use of the MIXED procedure of SAS (SAS Institute Inc., Cary, NC) with a model statement including farm and season and farm by season with a random effect of farm by season by year interaction using year as the replicate. Effects of pasture on the proportion of GPS observations within the water source or waterside zone of pastures in Study 2 were analyzed with the use of the MIXED procedure of SAS with a model statement of pasture and season and a random effect of pasture by season with season used as the replicate. Differences in botanical composition of farm pastures in Study 1 were analyzed by the MIXED procedure of SAS with a model statement that included farm and year using year as the blocking factor and farm within year as the random effect. Differences between means of farms or pastures with significant effects were determined by comparing the leastsquares means (LSMeans) with the use of the probability of difference (PDIFF) statement along with a Tukey adjustment. Significance was determined at a level of $P<0.05$ with a tendency expressed as $0.05<P \leq 0.10$.

The LOGISTIC procedure (SAS Institute) was utilized to analyze the effects of Temp, BGTemp, ET, THI, and BGTHI on the probability of cattle being in the waterside zone in both studies. Each GPS observation within the waterside zone was paired with each temperature or heat index and an odds ratio was calculated as the number of observations that a cow was within the waterside zone divided by the total number of observations at that temperature or heat index unit. The microclimatic variable that best predicted the presence of cattle within the waterside zones of each pasture was ambient temperature, as determined with the use of Akaike's information criteria (AIC; data not shown). Therefore, ambient temperature was used to compare differences between pastures for the probabilities that cattle were within the waterside zone.

To quantify the effects of pasture physical and botanical characteristics on the temporal/spatial distribution of grazing cattle in Study 1, regressions using the proportion of GPS measurements in the water source or waterside zones of pastures as dependent variables were calculated with independent variables of pasture size, proportion of waterside zone in each pasture, proportion of the total pasture shade located in the waterside zone, and proportion of tall fescue in the herbaceous vegetation of pastures (SAS Institute). To quantify the effects of pasture physical characteristics and shade distribution on the temporal/spatial distribution of grazing cattle in Study 2, regressions using the proportion of GPS measurements in the water source or waterside zones of pastures as dependent variables were calculated with independent variables of proportion of waterside zone in each pasture and the proportion of the total pasture shade located in the waterside zone (SAS Institute). In order to determine significant regression variables from the limited number of farms in the study, a Bonferroni adjustment was performed ( 0.05 divided by the number of regressions performed) to determine significant pasture characteristic effects. Significance was determined at a level of $P<0.0125$ and $P<0.025$ for Studies 1 and 2, respectively.

\section{RESULTS AND DISCUSSION}

\section{Study 1: Factors Influencing Cattle Distribution}

Cattle Distribution. Cattle from all pastures tended $(P<0.10)$ to spend a greater proportion of time in the water source during the summer $(4.24 \%)$ than fall $(2.79 \%)$ seasons, but were not different than spring $(3.20 \%$; data not shown). The proportion of time that cattle spent in the water source differed $(P<0.05)$ by farms. Cows on Farm D spent a greater proportion of time in the water source than cows on Farms A, B, and C, but were 


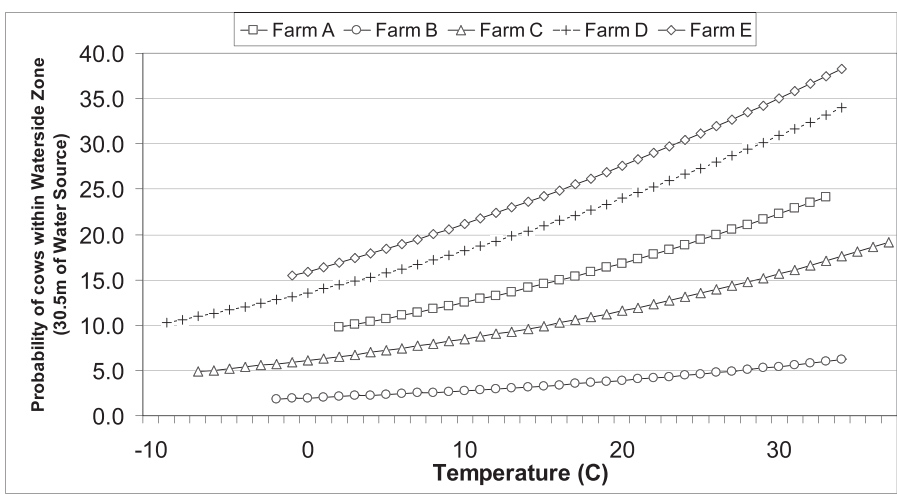

Figure 2. Effect of ambient temperature on the probability of cows in Study 1 located within the waterside zone ( $30.5 \mathrm{~m}$ of water source) by farms over the 3-yr study.

similar to cows on Farm E. Cows on Farm E were located in the water source a greater percentage of observations $(P<0.05)$ than cows on Farms $\mathrm{A}$ and $\mathrm{B}$, but not different $(P>0.10)$ from cows on Farm C. Cows on Farms A, B, and C were located in the water source a similar percentage of observations. However, season did not affect $(P>0.10)$ the proportion of time that cattle were located in the waterside zone. Cows on Farms D and $\mathrm{E}$ spent a greater percentage of time $(P<0.05)$ in the waterside zone compared to cows on Farms A and C, which spent a greater proportion of time in the waterside zone than cows on Farm B. The differences in the probabilities of being within the waterside zone among farms occurred across the range of ambient temperatures that occurred during the study (Fig. 2).

The proportions of time that cattle in this study spent in the water source are less than the results of other studies. Agouridis et al. (2004) found that cattle in 2.0- and 3.0-ha pastures in Kentucky spent nearly $8 \%$ and $14 \%$ of the time within $5 \mathrm{~m}$ of a stream. Byers et al. (2005) reported that cattle spent $5-13 \%$ of the time in the riparian area, defined as $12 \mathrm{~m}$ from the center of the stream, on 3.8-5.5-ha endophyte-infected tall fescue and common bermudagrass pastures in Georgia from May to August. Differences in vegetation, pasture characteristics, and climate may be responsible for the observed differences in cattle distribution.

Botanical Composition. The pastures primarily contained tall fescue and reed canarygrass with smaller proportions as other cool-season grasses: Kentucky bluegrass (Poa pratensis L.), smooth bromegrass (Bromus inermis L.), and orchardgrass (Dactylis glomerata L.), along with legumes: white clover (Trifolium repens L.), red clover (Trifolium pretense L.), and birdsfoot trefoil (Lotus corniculatus L.), and squarrose sedge (Carex squarrosa L.), broadleaf weeds, and shrubs. The proportions of reed canarygrass and legumes in the herbaceous vegetation and proportions of bare ground and shrubs in the pastures differed $(P<0.01$; Table 2$)$ among farms. There also tended $(P<0.10)$ to be differences for the proportion of tall fescue, other cool-season grasses, and sedge in the herbaceous vegetation among farms. There were no differences $(P>0.10)$ in proportion of broadleaf weeds in the herbaceous vegetation among farms. The most predominant forage species observed on four of the five farms was tall fescue, which ranged from $20 \%$ to $51 \%$ of the herbaceous vegetation. The predominant forage species on the remaining farm was reed canarygrass. In spite of each pasture having some area within and outside the physical riparian zone, herbaceous vegetation composition across each pasture was relatively homogeneous. Of the tall fescue tillers sampled from each pasture, 97, 85, 87, 84, and $84 \%$ were endophyte-infected on Farms A, B, C, D, and E, respectively.

Surprisingly, despite confirmation of endophyte-infected tall fescue in pastures, the proportion of tall fescue in the herbaceous vegetation only had a minimal influence on cattle distribution in the water source and did not influence $(P>0.10)$ cattle distribution in the waterside zone. Tall fescue containing the endophyte has been documented to cause severe vasoconstriction (Rhodes et al. 1991; Oliver et al. 1993; Aiken et al. 2007) and elevated body temperatures and respiration rates when livestock are under heat and humidity stress, such as late spring or summer periods (Hemken et al. 1981; Sprinkle et al. 2000; Al-Haidary et al. 2001). Because the proportion of time cattle were observed in water sources differed by farms in this study, the high proportion of endophyte-infected tall fescue observed in this study may have aided and caused heat stress, which could have caused congregation of the cattle near water sources during periods of increased temperatures or humidities. The lack of significant regressions between the proportion of time that cattle were in the waterside zone and the proportion of tall fescue in the herbaceous vegetation might be attributed to the limited range in this variable and/or the limited number of farms used. Lack of substantial effects of tall fescue on cattle observations in the water source and waterside zones may infer

Table 2. Proportion of sites with major forage species, sedge, broadleaf weeds, shrubs, or bare ground in pastures determined by visual observation to evaluate temporal/spatial distribution (Study 1).

\begin{tabular}{|c|c|c|c|c|c|c|c|c|}
\hline Farm & Tall fescue & Reed canarygrass & Other cool-season grasses & Legumes & Sedge & Broadleaf weeds & Shrubs & Bare ground \\
\hline & & . & of vegetated sites & ----------- & ------- & 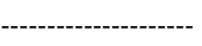 & \multicolumn{2}{|c|}{---- \% of all sites --.-- } \\
\hline$A^{1}$ & $20.1 \mathrm{y}$ & $45.5 \mathrm{a}$ & $3.8 \mathrm{y}$ & $3.5 b$ & $6.4 x$ & 20.7 & $7.0 \mathrm{~b}$ & $12.9 \mathrm{a}$ \\
\hline $\mathrm{B}^{1}$ & $37.0 x y$ & $1.1 \mathrm{c}$ & $4.6 \mathrm{y}$ & $10.5 \mathrm{~b}$ & $4.6 x$ & 42.2 & $17.0 \mathrm{a}$ & $13.7 \mathrm{a}$ \\
\hline$C^{1}$ & $51.5 x$ & $0.7 \mathrm{c}$ & $4.2 \mathrm{y}$ & $18.4 \mathrm{a}$ & $3.9 x$ & 21.3 & $2.6 \mathrm{~b}$ & $5.0 \mathrm{~b}$ \\
\hline$D^{2}$ & $42.0 x$ & $13.0 \mathrm{~b}$ & $8.6 x y$ & $9.3 \mathrm{~b}$ & $4.2 x$ & 22.9 & $13.6 \mathrm{a}$ & $12.5 \mathrm{a}$ \\
\hline$E^{2}$ & $44.1 x$ & $0.9 \mathrm{c}$ & $14.4 x$ & $19.2 \mathrm{a}$ & $1.3 \mathrm{y}$ & 20.1 & $2.1 \mathrm{~b}$ & $9.2 \mathrm{ab}$ \\
\hline
\end{tabular}

${ }^{1}$ Species of the individual plant or bare ground located at the center and four equidistant locations from the center of each square of a $100 \times 100 \mathrm{~m}$ grid across each pasture.

${ }^{2}$ Species of the individual plant or bare ground located at the center and four equidistant locations from the center of each square of a $50 \times 50 \mathrm{~m}$ grid across each pasture.

a,b,cWithin a column, least-squares means without a common subscript differ $(P<0.05)$ by farm.

${ }^{x, y}$ Within a column, least-squares means without a common subscript tended to differ $(P<0.10)$ by farm. 


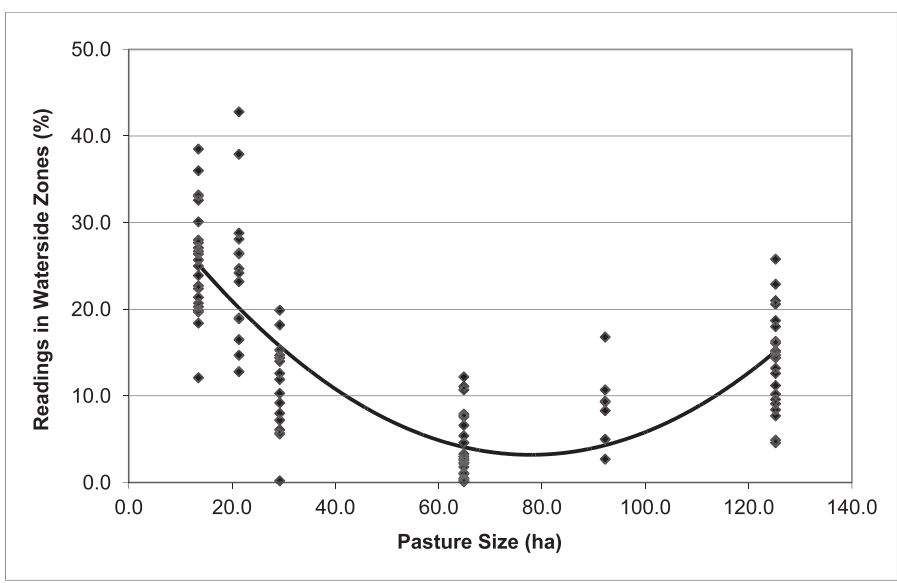

Figure 3. Effect of size of pastures on the percentage of GPS collar readings of cattle distribution patterns in the waterside zones of pastures (Study 1). $Y=35.40-0.83 x+0.0053 x^{2} ;\left(r^{2}=0.61\right)$

that additional pasture characteristics were superseding the effects of tall fescue on cattle distribution.

Pasture Size and Shape. Pasture size influenced $(P<0.0001)$ the proportion of time grazing cattle were located in the water source and waterside zones of the pastures. Pasture size accounted for $22 \%$ and $61 \%$, respectively, of the variation of total GPS observations within the water source (data not shown) and waterside zone (Fig. 3). Because reducing pasture size may alter forage utilization patterns and reduce the distance livestock travel to water (Hart et al. 1993), the disproportional amount of time livestock may spend in waterside zones of small pastures may impact residual forage height (Clary and Leininger 2000; DelCurto et al. 2005), hoof traffic (Betteridge et al. 1999), and the amounts of fecal and urinary nutrients excreted in the waterside zones of small pastures compared to larger pastures (Tate et al. 2003).

The proportion of the total pasture area within the waterside zone influenced GPS observations of cattle in waterside zones, accounting for $36 \%$ (Fig. 4) of the variation of GPS observations of cows in the waterside zones of pastures during Study 1 .

Shade Distribution. The proportion of the total pasture shade within the waterside zone accounted for $29 \%$ (data not shown) of the variation in the proportion of GPS observations within the waterside zone over the $3 \mathrm{yr}$. Confounding effects of pasture size and shape in varying-sized pastures in Study 1 may have superseded shade effects influencing cattle distribution. However, because only five pastures with widely varying characteristics were utilized in this project, any relationship inferred by these data should be interpreted with some caution.

\section{Study 2: Pasture Shape and Shade Distribution Effects on Cattle Distribution}

Pasture Shape. Although it was intended to have pastures of comparable size, the three pastures in Study 2 varied by 8.015.1 ha. The variation in pasture size was due to the pasture location along a major river with streams in an attempt to minimize the number of water gaps while controlling the shade

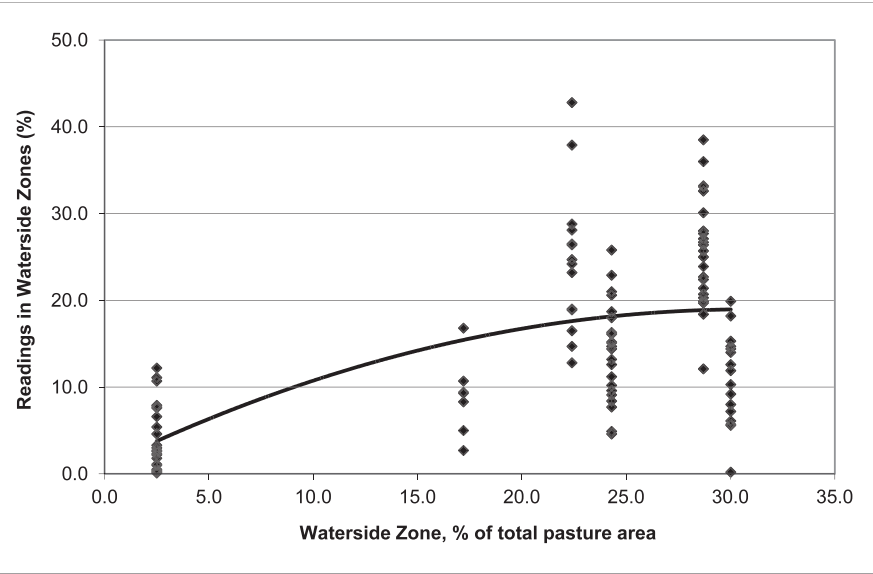

Figure 4. Effect of proportion of total pasture area in the waterside zones of pastures on the percentage of GPS collar readings of cattle distribution patterns in the waterside zones of pastures (Study 1). $Y=0.99+1.169 x-0.019 x^{2} ;\left(r^{2}=0.36\right)$

distribution within the pastures. However, in these pastures, the proportion of the pasture within the waterside zone accounted for $62 \%$ (Fig. $5 \mathrm{a}$ ) of the variation of GPS cow observations in the waterside zone during the 1-yr grazing trial. Similar to the current study, pasture shape, orientation, and location influence grazing behavior of livestock (Hart et al. 1993), which may influence the proportion of time cattle are within the water source and waterside zone. Without the opportunity to distribute in other areas, greater nutrient excretion (Tate et al. 2003) and treading damage (Elliott et al. 2002) from livestock near surface waters may increase the risk of nonpoint source (NPS) pollution occurring from grazed pastures.

Shade Distribution. The proportion of total pasture shade located within the waterside zone accounted for $42 \%$ (Fig. 5 b) of the variation of GPS observations in the waterside zone of pastures of comparable size, implying that shade distribution influenced cattle distribution. However, similar to Study 1, these relationships are being inferred from a limited number of pastures and limited ranges in the proportions of total pasture area and shade. The mean proportion of cow observations in Pastures $1 \mathrm{~N}$ and $3 \mathrm{~S}$ were in the waterside zone differed by $0.52 \%$. Because the differences in the proportions of total pasture area and shade in waterside zone of Pastures $1 \mathrm{~N}$ and $3 \mathrm{~S}$ were $28.7 \%$ and $5.0 \%$ units, it seems that pasture shape was a more important determinant of cow distribution than shade in this study.

Shade is an important management strategy that producers may utilize in pastures during high ambient temperatures (Schmidt and Osborn 1993; Sigua and Coleman 2007), periods of high solar radiation (Tucker et al. 2008), and periods of increasing relative humidity (Black Rubio et al. 2008) to reduce the heat load in an attempt to maintain thermal equilibrium (Blackshaw and Blackshaw 1994). Providing nonriparian shade in pastures may encourage cattle to distribute away from surface waters, decreasing the risk of fecal loading (Byers et al. 2005) and promoting more uniform grazing within a pasture (McIlvin and Shoop 1971; Hacker et al. 1988; Laca 2009). 

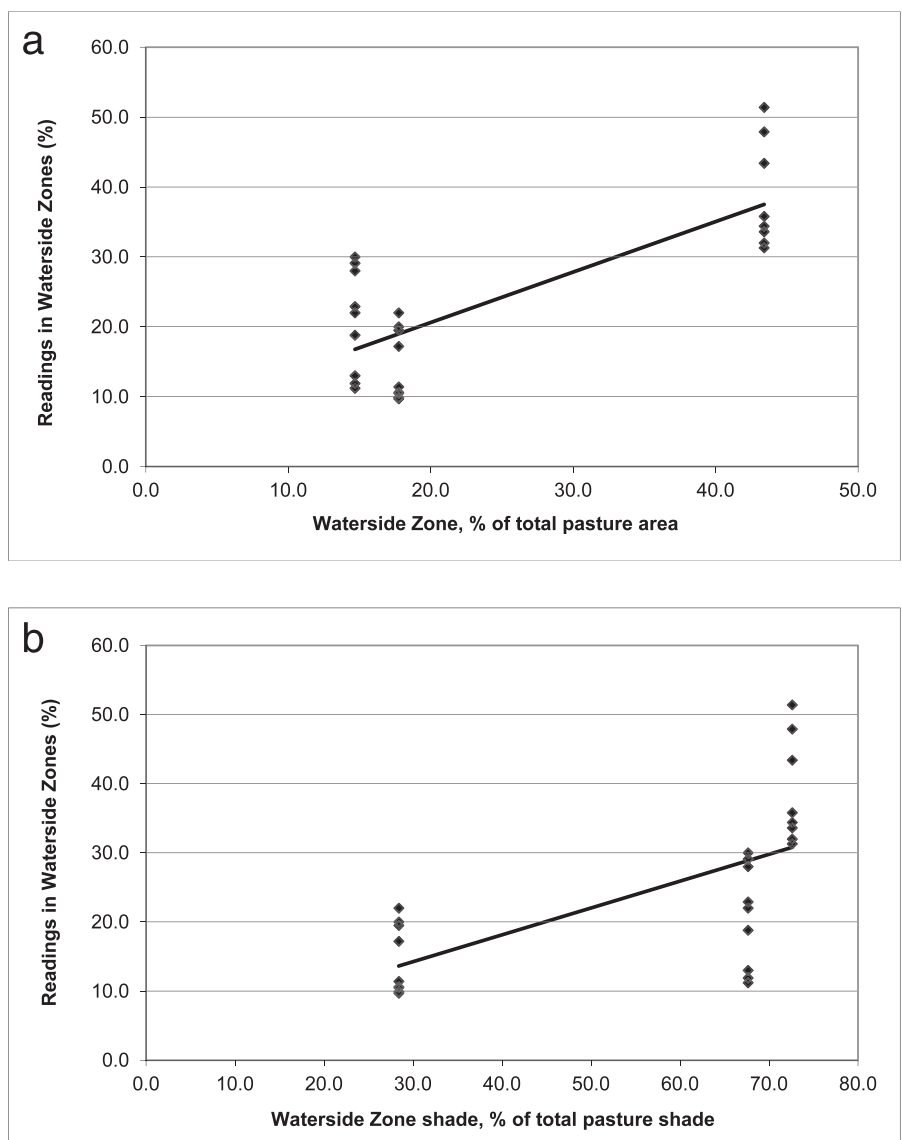

Figure 5. Proportion of GPS cattle observations in waterside zone as affected by the $\mathbf{a}$, proportion of total pasture area in the waterside zone, and b, proportion of total pasture shade in the waterside zone of each pasture (Study 2). (a) $Y=6.16+0.72 x ; \quad\left(r^{2}=0.62\right)$. (b) $Y=2.58+0.39 x$; $\left(r^{2}=0.42\right)$.

It can be inferred by the results of these two studies that more restrictive management practices such as establishing the riparian buffers (McKergow et al. 2003; Muenz et al. 2006; Webber et al. 2010), restricting stream access to stabilized crossings (Haan et al. 2010), or limiting grazing of riparian paddocks (Haan et al. 2010) may be necessary to minimize nonpoint source pollution of streams in small or narrow pastures. In future studies evaluating the temporal/spatial distribution of grazing cattle, it would be advantageous for researchers to report pasture size, shape, and shade distribution with any treatments that are being tested to influence cattle distribution. Further studies are necessary to define the optimal pasture size and identify the best management practices appropriate for pastures with different sizes, shapes, and shade distributions to provide the most cost-effective approach to minimize NPS pollution risks from midwestern pastures.

\section{MANAGEMENT IMPLICATIONS}

Exclusion from streams within riparian buffers (McKergow et al. 2003; Muenz et al. 2006; Webber et al. 2010) or limiting stream access to stabilized access sites (Haan et al. 2010;
Schwarte et al. 2011) or within riparian paddocks of a rotational stocking system (Haan et al. 2010; Schwarte et al. 2011) have been effective in reducing the proportion of time grazing cattle are near or in pasture streams and, thereby, the risks of sediment, nutrient, and pathogen loading of streams. However, results of this study revealed that the proportion of time that cattle are near streams in midwestern pastures is highly related to pasture size and shade distribution. Therefore, implementation of management practices to limit NPS pollution of streams in midwestern pastures should be based on the physical characteristics of each site. In large pastures, use of fences to prevent or limit access of grazing cattle to pasture streams may not be necessary to minimize NPS pollution of pasture streams by congregation of cattle near streams, particularly if shade is present outside the riparian zone. But management practices that utilize fences to prevent or limit access of cattle to pasture streams may be necessary to minimize the risks of NPS pollution of streams resulting from cattle congregating near streams in small or narrow pastures in which cattle have less opportunity to travel to upland locations.

\section{ACKNOWLEDGMENTS}

The authors thank the cooperating southern Iowa cattle producers for the opportunity to work on their farms and cattle, Dennis Maxwell and Kevin Maher at McNay Research and Demonstration Farm for their assistance and management of cattle, the Engineering Services Group, Ames Laboratory, US Department of Energy, Iowa State University, for construction of the custom prototype GPS collars, Garritt Page and Jon Hobbs of the Department of Statistics, Iowa State University, for their assistance with statistical analysis, and personnel staff at US Department of Agriculture-Natural Resources Conseravtion Service in Corydon, IA and the Rathbun Rural Water Alliance.

\section{LITERATURE CITED}

Agouridis, C. T., D. R. Edwards, E. Vanzant, J. Bicudo, J. L. Taraba, and R. S. Gates. 2004. Influence of BMPs on Cattle Position Preference. ASAE/CSAE Meeting Paper No. 042182. St. Joseph, MI, USA: ASAE.

Aiken, G. E., B. H. Kirch, J. R. Strickland, L. P. Bush, M. L. Looper, and F. N. Schrick. 2007. Hemodynamic responses of the caudal artery to toxic tall fescue in beef heifers. Journal of Animal Science 85:2337-2345.

Al-Haidary, A., D. E. Spiers, G. E. Rottinghaus, G. B. Garner, and M. R. Ellersieck. 2001. Thermoregulatory ability of beef heifers following intake of endophyteinfected tall fescue during controlled heat challenge. Journal of Animal Science 79:1780-1788.

Balley, D. W., J. E. Gross, E. A. Laca, L. R. Rittenhouse, M. B. Coughenour, D. M. Swift, AND P. L. Sims. 1996. Mechanisms that result in large herbivore grazing distribution patterns. Journal of Range Management 49:386-400.

BAllEY, D. W. 2005. Identification and creation of optimum habitat conditions for livestock. Rangeland Ecology \& Management 58:109-118.

Balley, D. W., H. C. VanWagoner, R. Weinmeister, and D. Jensen. 2008. Comparison of low-moisture blocks and salt for manipulating grazing patterns of beef cows. Journal of Animal Science 86:1271-1277.

Ballard, T. M., and W. C. Krueger. 2005. Cattle and salmon I: Cattle distribution and behavior in a northeastern Oregon riparian ecosystem. Rangeland Ecology \& Management 58:267-273.

Belsky, A. J., A. Matske, and S. Uselman. 1999. Survey of livestock influences on stream and riparian ecosystems in the western United States. Journal of Soil and Water Conservation 54:419-431. 
Betteridge, K., A. D. Mackay, T. G. Shepherd, D. J. Parker, P. J. Budding, B. P. Devantier, and D. A. Costall. 1999. Effect of cattle and sheep on surface configuration of a sedimentary hill soil. Australian Journal of Soil Research 37:743-760.

Black Rubio, C. M., A. F. Cibils, R. L. Endecott, M. K. Petersen, and K. G. Boykin. 2008. Pinyon-juniper woodland use by cattle in relation to weather and animal reproductive state. Rangeland Ecology \& Management 61:394-404.

BlackSHAW, J. K., AND A. W. BlackShaW. 1994. Heat stress in cattle and the effect of shade on production and behavior: a review. Australian Journal of Experimental Agriculture 34:285-295.

Buffington, D. E., A. Collazo-Arocho, G. H. Canton, D. Pitt, W. W. Thatcher, and R. J. Coluler. 1981. Black globe-humidity index (BGHI) as comfort equation for dairy cows. American Society of Agricultural Engineers 24:711-714.

Bryant, L. D. 1982. Response of livestock to riparian zone exclusion. Journal of Range Management 35:780-785.

Byers, H. L., M. L. Cabrera, M. K. Matthews, D. H. Franklin, J. G. Andrae, D. E. Radcliffe, M. A. McCann, H. A. Kuykendall, C. S. Hoveland, and V. H. Calvert II. 2005. Phosphorus, sediment, and Escherichia coli loads in unfenced streams of the Georgia Piedmont, USA. Journal of Environmental Quality 34:2293-2300.

Castañeda, C. A., J. B. Gaughan, and Y. Sakaguchi. 2003. Relationships between climatic conditions and the behaviour of feedlot cattle. Animal Production in Australia 25:33-36.

Clary, W. P., AND W. C. Leininger. 2000. Stubble height as a tool for management of riparian areas. Journal of Range Management 53:562-573.

DelCurto, T., M. Porath, M. Mclnnis, P. Momont, and C. Parsons. 1999. Management strategies for optimal beef cattle distribution and use of mountain riparian meadows. In: K. L. Launchbaugh, K. D. Sanders, and J. C. Mosley [EDS.]. Grazing behavior of livestock and wildlife. Moscow, ID, USA: Idaho Forest, Wildlife, and Range Experiment Station. Bull. No. 70. p. 119-129.

DelCurto, T., M. Porath, C. T. Parsons, and J. A. Morrison. 2005. Management strategies for sustainable beef cattle grazing on forested rangelands in the Pacific Northwest. Rangeland Ecology \& Management 58:119-127.

Elloott, A. H., Y. Q. Tian, J. C. Rutherford, and W. T. Carlson. 2002. Effect of cattle treading on interrill erosion from hill pasture: modeling concepts and analysis of rainfall simulator data. Australian Journal of Soil Research 40:963-976.

Franklin, D. H., M. L. Cabera, H. L. Byers, M. K. Matthews, J. G. Andrae, D. E. Radcliffe, M. A. McCann, H. A. Kuykendall, C. S. Hoveland, and V. H. Calvert II. 2009. Impact of water troughs on cattle use of riparian zones in the Georgia Piedmont, USA Journal of Animal Science 87:2151-2159.

Fuouay, J. W. 1981. Heat stress as it affects animal production. Journal of Animal Science 52:164-174.

Gaughan, J. B., T. L. Mader, S. M. Holt, and A. Lisle. 2008. A new heat load index for feedlot cattle. Journal of Animal Science 86:226-234.

Ganskopp, D. C., AND D. W. BohneRt. 2009. Landscape nutritional patterns and cattle distribution in rangeland pastures. Applied Animal Behaviour Science 116:110 119.

Haan, M. M., J. R. Russell, J. R. Davis, and D. G. Morrical. 2010. Grazing management and microclimate effects on cattle distribution relative to a cool season pasture stream. Rangeland Ecology \& Management 63:572-580.

Hacker, R. B., B. E. Norton, M. K. Owens, and D. 0. Frye. 1988. Grazing of crested wheatgrass, with particular reference to effects of pasture size. Journal of Range Management 41:73-78.

Hart, R. H., J. Bissio, M. J. Samuel, and J. W. Waggoner, JR. 1993. Grazing systems, pasture size, and cattle grazing behavior, distribution and gains. Journal of Range Management 46:81-87.

Hemken, R. W., J. A. Boling, L. S. Bull, R. H. Hatton, R. C. Buckner, and L. P. Bush. 1981. Interaction of environmental temperature and anti-quality factors on the severity of summer fescue toxicosis. Journal of Animal Science 52:710-714.

Hermann, M. L., J. R. Russell, and S. K. Barnhart. 2002. Evaluation of hay-type and grazing-tolerant alfalfa cultivars in season-long or complementary rotational stocking systems for beef cows. Journal of Animal Science 80:768-779.

Kauffman, J. B., And W. C. Krueger. 1984. Livestock impacts on riparian ecosystems and streamside management implications-a review. Journal of Range Management 37:430-438.

LACA, E. A. 2009. New approaches and tools for grazing management. Rangeland Ecology \& Management 62:407-417
Mader, T. L., M. S. Davis, and T. Brown-Brandl. 2006. Environmental factors influencing heat stress in feedlot cattle. Journal of Animal Science 84:712-719.

Mclivin, E. H., AND M. C. Shoop. 1971. Shade for improving cattle gains and rangeland use. Journal of Range Management 24:181-184.

MclnNIS, M. L., AND J. Mclver. 2001. Influence of off-stream supplements on stream banks of riparian pastures. Journal of Range Management 54:648-652.

McKergow, L. A., D. M. Weaver, I. P. Prosser, R. B. Grayson, and A. E. G. Reed. 2003 Before and after riparian management: sediment and nutrient exports from a small agricultural catchment, Western Australia. Journal of Hydrology 270:253272.

Meat and Livestock Australia. 2002. Recognising excessive heat load in feedlot cattle. On farm tips and tools. Feedlot FL10.

Muenz, T. K., S. W. Golladay, G. Vellidis, and L. L. Smith. 2006. Stream buffer effectiveness in an agriculturally influenced area, southwestern Georgia: Responses of water quality, macroinvertebrates, and amphibians. Journal of Environmental Quality 35:1924-1938.

Oliver, J. W., L. K. Abney, J. R. Strickland, and R. D. Linnabary. 1993. Vasoconstriction in bovine vasculature induced by the tall fescue alkaloid lysergamide. Journal of Animal Science 71:2708-2713.

Owens, M. K., K. L. Launchbaugh, and J. W. Holloway. 1991. Pasture characteristics affecting spatial distribution of utilization by cattle in mixed brush communities. Journal of Range Management 44:118-123.

Rhodes, M. T., J. A. Paterson, M. S. Kerley, H. E. Garnet, and M. H. Laughlin. 1991. Reduced blood flow to peripheral and core body tissues in sheep and cattle induced by endophyte-infected tall fescue. Journal of Animal Science 69:20332043.

[RLWA] Rathbun Land and Water Alliance. 2001. Assessment and management strategies for the Rathbun Lake Watershed. Corydon, IA, USA: Rathbun Land and Water Alliance. $189 \mathrm{p}$

Schmidt, S. P., AND T. G. Osborn. 1993. Effects of endophyte-infected tall fescue on animal performance. Agriculture, Ecosystems, \& Environment 44:233-262.

Schwarte, K. A., J. R. Russell, and D. G. Morrical. 2011. Effects of pasture management and off-stream water on temporal $\backslash$ spatial distribution of cattle and stream bank characteristics in cool-season grass pastures. Journal of Animal Science 89:3236-3247.

Sevi, A., A. Muscio, D. Dantone, V. Iascone, and F. D’Emilio. 2001. Paddock shape effects on grazing behavior and efficiency in sheep. Journal of Range Management 54:122-125.

Sigua, G. C., And S. W. Coleman. 2007. Sustainable management of nutrients in forage-based pasture soils: effect of animal congregation sites. Journal of Soils and Sediments 6:249-253.

Sprinkle, J. E., J. W. Holloway, B. G. Warrington, W. C. Ellis, J. W. Stuth, T. D. A. Forbes, AND L. W. GreENE. 2000. Digesta kinetics, energy intake, grazing behavior and body temperature of grazing beef cattle differing in adaptation to heat. Journal of Animal Science 78:1608-1624.

Tate, K. W., E. R. Atwill, N. K. Mcdougald, and M. R. George. 2003. Spatial and temporal patterns of cattle feces deposition on rangeland. Journal of Range Management 56:432-438.

TUCKER, C. B., A. R. RogeRS, AND K. E. SchÜtz. 2008. Effect of solar radiation on dairy cattle behaviour, use of shade and body temperature in a pasture-based system. Applied Animal Behavior Science 109:141-154.

Webber, D. F., S. K. Mickelson, S. I. Ahmed, J. R. Russell, W. J. Powers, R. C. Schultz, AND J. L. Kovar. 2010. Livestock grazing and vegetative filter strip buffer effects on runoff sediment, nitrate, and phosphorus losses. Journal of Soil and Water Conservation 65:34-41.

White, S. L., R. E. Sheffield, S. P. Washburn, L. D. King, and J. T. Green, JR. 2001 Spatial and time distribution of dairy cattle excreta in an intensive pasture system. Journal of Environmental Quality 30:2180-2187.

Yamamoto, S., B. A. Young, B. P. Purwanto, F. Nakamasu, and T. Matsumoto. 1994. Effect of solar radiation on the heat load of dairy heifers. Australian Journal of Agricultural Research 45:1741-1749.

Youser, M. K. 1985. Stress physiology in livestock: ungulates. Vol. 2. Boca Raton, FL, USA: CRC Press. $261 p$

Zuo, H., AND M. S. MIller-Goodman. 2004. Landscape use by cattle affected by pasture developments and season. Journal of Range Management 57:426-434. 